\title{
Evaluation and calibration of downward longwave radiation models under cloudless sky at Ile-Ife, Nigeria
}

\author{
Olanrewaju Olukemi SONEYE-AROGUNDADE
}

Department of Physics, Anchor University Lagos, Nigeria.

Email: olanrewaju.soneye@gmail.com

Received: February 27, 2020; accepted: July 31, 2020

\begin{abstract}
RESUMEN
La radiación descendente de onda larga es una variable importante para calcular la radiación neta, con el fin de investigar el balance de energía superficial y realizar estudios climáticos. Por lo general el flujo se calcula con base en información de parámetros meteorológicos como humedad relativa, temperatura superficial y del aire, y presión del vapor de agua. En este trabajo se realiza una valoración de 11 modelos empíricos ampliamente utilizados para calcular la radiación descendente de onda larga, utilizando para ello una base de datos de superficie reunida entre enero de 2016 y diciembre de 2017 en Ile-Ilfe, una ciudad tropical de Nigeria. Los modelos originales de Idso y de Niemela et al. tuvieron un mejor desempeño que el resto, con un margen de error de menos de $5 \%$ en comparación con los datos de superficie. El desempeño de todos lo modelos mejoró de manera importante después de la calibración. El modelo de Guest, que arrojó pequeños errores $\left(\mathrm{MBE}=0.65 \mathrm{Wm}^{-2}, \mathrm{RMBE}=0.15 \%, \mathrm{RMSE}=9.38 \mathrm{Wm}^{-2}, \mathrm{RRMSE}=2.14 \%, \mathrm{MAE}=7.84 \mathrm{Wm}^{-2}\right.$, RMAE $=1.79 \%$ ), tuvo el mejor desempeño, seguido por los de Dilley y O'Brien, Idso, Prata, Brutsaert, Garratt, Niemela et al. y Ångström. Los modelos calibrados que se presentan en este estudio pueden usarse para calcular el flujo en condiciones de cielo despejado tanto en Ile-Ilfe como en otros sitios con patrones meteorológicos similares, donde dicho flujo no pueda medirse en superficie debido a problemas técnicos y al alto costo de adquirir y mantener los sensores necesarios. El modelo propuesto para calcular el flujo se comportó mejor que todos los modelos empíricos probados, con errores estadísticos menores que éstos y excelente concordancia $\left(\mathrm{R}^{2}=0.88\right)$ con los datos medidos.
\end{abstract}

\begin{abstract}
Downward longwave radiation flux is an important variable for estimating net radiation, in order to investigate the surface energy budget and carry out climatic studies. The flux is usually estimated using empirical models based on the information of meteorological parameters such as relative humidity, surface and air temperature, and water vapor pressure. This paper presents the assessment of 11 widely used empirical models for estimating downward longwave radiation using a ground-based dataset acquired from January 2016 to December 2017 at Ile-Ife, a tropical city in Nigeria. The original Idso and Niemela et al. models performed better than other models with errors less than $5.0 \%$ when compared to measured values. The performances of all the models improved greatly after calibration. The Guest model, which gave low errors (MBE $=0.65 \mathrm{Wm}^{-2}$, RMBE $=0.15 \%$, RMSE $=9.38 \mathrm{Wm}^{-2}, \mathrm{RRMSE}=2.14 \%, \mathrm{MAE}=7.84 \mathrm{Wm}^{-2}, \mathrm{RMAE}=1.79 \%$ ), performed best followed by the Dilley and O’Brien, Idso, Prata, Brutsaert, Garratt, Niemela et al., and Ångström models. The calibrated models presented in this study can be used to estimate the flux under cloudless sky conditions at Ile-Ife and at other places with similar meteorological conditions, where this flux is not measured due to technological problems and the high cost of purchasing and maintaining the needed sensors. The proposed model for estimating the flux showed better performance with lower statistical errors than all the existing empirical models tested, and conform greatly $\left(\mathrm{R}^{2}=0.88\right)$ to the measured data.
\end{abstract}

Keywords: surface energy budget, downward longwave radiation, cloudless sky, calibration coefficient, statistical errors, meteorological parameters. 


\section{Introduction}

The downward (atmospheric) longwave radiation flux $\left(L_{\downarrow}\right)$ is one of the components of longwave radiation that reaches the Earth's surface after being emitted by the atmosphere and all its constituents (Oke, 2002; Duarte et al., 2006; Guo et al., 2018). It is an important component of net radiation and can be expressed as shown in Eq. (1) if the entire atmosphere is considered as a grey body with an effective atmospheric emissivity $\left(\varepsilon_{\mathrm{A}}\right)$ and air temperature $\left(T_{\mathrm{A}}\right)$ (Paltridge and Platt, 1976; Prata, 1996; Guo et al., 2018).

$L_{\downarrow}=\varepsilon_{A} \sigma T_{A}^{4}$

where $\sigma$ is the Stefan-Boltzmann constant with a value of $5.67 \times 10^{-8} \mathrm{Wm}^{-2} \mathrm{~K}^{-4}$ and $\varepsilon_{\mathrm{A}}$ is dimensionless, while the units of $L_{\downarrow}$ and $T_{\mathrm{A}}$ are $\mathrm{Wm}^{-2}$ and $\mathrm{K}$, respectively. Eq. (1) implies that under cloudless sky conditions $\varepsilon_{\mathrm{A}}$ depends on the vertical temperature profile and it can be modeled as a function of water vapor pressure, air temperature or both, which are routinely measured at various meteorological sites and well documented (Alados et al., 2011; Carmona et al., 2014; Guo et al., 2018).

The knowledge on the downward longwave radiation flux is very useful in the determination of net radiation, energy balance, global warming and the construction of radiant cooling systems (Crawford and Duchon, 1999; Arya, 2001; Gröbner et al., 2009; Carmona et al., 2014). However, data of this flux are not often available at various meteorological stations due to technological problems and the high cost of the sensors (pyrgeometers) needed for measuring the flux and their maintenance. This led to the development of different empirical models by many authors for estimating this flux under cloudless skies at the Earth's surface, based on information of meteorological parameters (such as relative humidity, water vapor pressure, air temperature, etc.) (Crawford and Duchon, 1999; Kruk et al., 2010). Still, as good as all the developed empirical models may be, they are less accurate for estimating the flux under cloudless sky conditions at a tropical region such as Nigeria. This is due to differences in climatic conditions and the areas where the coefficients of the models were developed. Apart from the developed empirical models, various radiative transfer codes (such as MODTRAN, STREAMER, LOWTRAN and SBDART) and radiative transfer models have been used by various authors (e.g., Kneizys et al., 1988; Snell et al., 1995; Key and Schweiger, 1998; Ricchiazzi et al., 1998) to study the flux as well as various atmospheric absorption and emission processes. One of the disadvantages of the radiative transfer models and codes is that the required data (such as vertical water vapor, properties of clouds, atmospheric aerosols, air temperature and relative humidity profiles) are not readily available, especially in tropical regions (Niemela et al., 2001; Duarte et al., 2006; Carmona et al., 2014).

The first empirical expression for parameterizing the downward longwave radiation under cloudless sky conditions based on Eq. (1) was developed by Ångström (1929). After this first expression, various empirical models have been proposed and developed by authors such as Swinbank (1963), Idso and Jackson (1969), Deacon (1970), Staley and Jurica (1972), Brutsaert (1975), Idso (1981), Garratt (1992), Culf and Gash (1993), Prata (1996), Dilley and O'Brien (1998), Guest (1998), and Niemela et al. (2001), among others. Some of the developed empirical equations have been used to parameterize the downward longwave radiation flux at different weather conditions and locations (Howard and Stull, 2013; Carmona et al., 2014; Alaa et al. 2017; Guo et al., 2018). The applications of all the developed empirical models to parameterize the flux at both the regional and global scales are unknown. Consequently, the aim of this paper is to assess the performances of existing and widely used empirical downward longwave radiation models for clear sky conditions and calibrate these models by using surface data measured at Ile-Ife, Nigeria, which is a tropical site. In addition, the performance of a new model developed for estimating the flux is evaluated.

\section{Materials and methods}

\subsection{Clear-sky downward longwave radiation mo-} dels

Eleven previously published empirical models were used for estimating the downward longwave radiation flux under cloudless sky conditions. Some of the developed models are presented in Table I.

\subsection{Study site and ground data}

The meteorological site where the data used for this study were acquired is located at the Teaching and 
Table I. Clear-sky downward longwave radiation models.

\begin{tabular}{|c|c|c|}
\hline Authors & Models & Definition of terms \\
\hline Ångström (1929) & $\left.L_{\downarrow C l}=0.83-0.18 \times 10^{-0.067 e_{0}}\right) \sigma T_{A}^{4}$ & $\begin{array}{l}e_{0} \text { is water vapor in hectopascales } \\
e_{0}=R H / 100\{1.33322368[\exp (20.386- \\
\left.\left.\left.5132 / T_{A}\right)\right]\right\} \\
R H \text { is the relative humidity in percentage }\end{array}$ \\
\hline Swinbank (1963) & $L_{\downarrow}=\left(0.94 \times 10^{-5} T_{A}^{2}\right) \sigma T_{A}^{4}$ & \\
\hline Idso and Jackson (1969) & $\begin{array}{l}L_{\downarrow}=\left\{1-0.261 \exp \left[-7.77 \times 10^{-4}\right.\right. \\
\left.\left(273-T_{A}^{2}\right]\right\} \sigma T_{A}^{4}\end{array}$ & \\
\hline Deacon (1970) & $\begin{array}{l}L_{\downarrow}=\left(0.94 \times 10^{-5} T_{A}^{2}\right) \sigma T_{A}^{4}- \\
{[0.035(\mathrm{Z} / 1000)] \sigma T_{A}^{4}}\end{array}$ & $\begin{array}{l}Z \text { is the altitude of the meteorological } \\
\text { site in meters }\end{array}$ \\
\hline Brutsaert (1975) & $L_{\downarrow C l}=1.24\left(e_{0} / T_{A}\right)^{1 / 7} \sigma T_{A}^{4}$ & \\
\hline Idso (1981) & $\begin{array}{l}L_{\downarrow C l}=\left[0.7+5.95 \times 10^{-5} e_{0}\right. \\
\left.\exp \left(1500 / T_{A}\right)\right] \sigma T_{A}^{4}\end{array}$ & \\
\hline Garratt (1992) & $L_{\downarrow}=\left[0.79-0.174 \exp \left(-0.095 e_{0}\right)\right] \sigma T_{A}^{4}$ & \\
\hline Prata (1996) & $\begin{array}{l}L_{\downarrow C l}=(1-[(1+w) \\
\left.\left.\exp \left(-(1.2+3.0 w)^{0.5}\right)\right]\right) \sigma T_{A}^{4}\end{array}$ & $\begin{array}{l}w \text { is the precipitable water content in } \mathrm{kg} \mathrm{m}^{-2} \\
w=465\left(e_{0} / T_{A}\right)\end{array}$ \\
\hline Dilley and O'Brien (1998) & $\begin{array}{l}L_{\downarrow C l}=59.38+113.7\left(T_{A} / 273.16\right)^{6}+ \\
96.96 \sqrt{(w / 25)}\end{array}$ & \\
\hline Guest (1998) & $L_{\downarrow C l}=\sigma T_{A}^{4} 1.0438+0.2486 R H-113.6$ & \\
\hline Niemela et al. (2001) & $L_{\downarrow} C l=\left[0.72+0.009\left(e_{0}-2\right)\right] \sigma T_{A}^{4}$ & If $e_{0} \geq 2$ \\
\hline
\end{tabular}

Research Farm, Obafemi Awolowo University Ile-Ife ( $7^{\circ} 33^{\prime} 18^{\prime \prime} \mathrm{N} ; 4^{\circ} 33^{\prime} 97^{\prime}$ E), Nigeria (Fig. 1). The site, covered by grass, is located within the tropical zone of West Africa at an altitude of 300 masl and has an area of $50 \times 100 \mathrm{~m}^{2}$. The climate may be characterized as alternative wet and dry periods that span between March/April to October, and November to February, respectively (Griffiths, 1974; Ayoola et al., 2014; Soneye et al., 2019). In this area, variations and changes in the season's patterns are a result of the meridional (north-south) movement of the Inter-Tropical Convergence Zone (ITCZ) across West Africa. The ITCZ at the surface demarcates the warm and moist (maritime) south-westerly wind from the hot and dry (continental) north-easterly trade winds blowing from the Saharan desert around Libya and Azores subtropical high-pressure system (Hastenrath 1991; Jegede et al., 2006; Oladosu et al., 2007). The moist south-westerlies usually form a wedge pushing northwards under the dry north-easterlies. This intersection migrates and attains its most northerly position at $22.25^{\circ} \mathrm{N}$ in August (Okogbue, 1997). Consequently, the south-west monsoon winds penetrate far into the West/North African hinterland covering the whole of Nigeria, bringing moisture and rain into the Sahel and Southern Sahara. Between late August and early September, the ITCZ starts to recede southwards until it reaches its most northerly position around $12-14^{\circ} \mathrm{N}$. In January, the north-easterly winds (very dry winds known locally as the Harmattan) dominate over most of the region, bringing dust as far south as the West African coast (Okogbue, 1997; Falaiye et al., 2014; Soneye, 2018). In this area, the sunrise and sunset times are around 07:00 and 19:00 LT, respectively (Ayoola et al., 2014; Soneye et al., 2019), while the yearly average air temperature and relative humidity are about $26.7^{\circ} \mathrm{C}$ and $80.1 \%$, respectively. Mean yearly rainfall ranges 

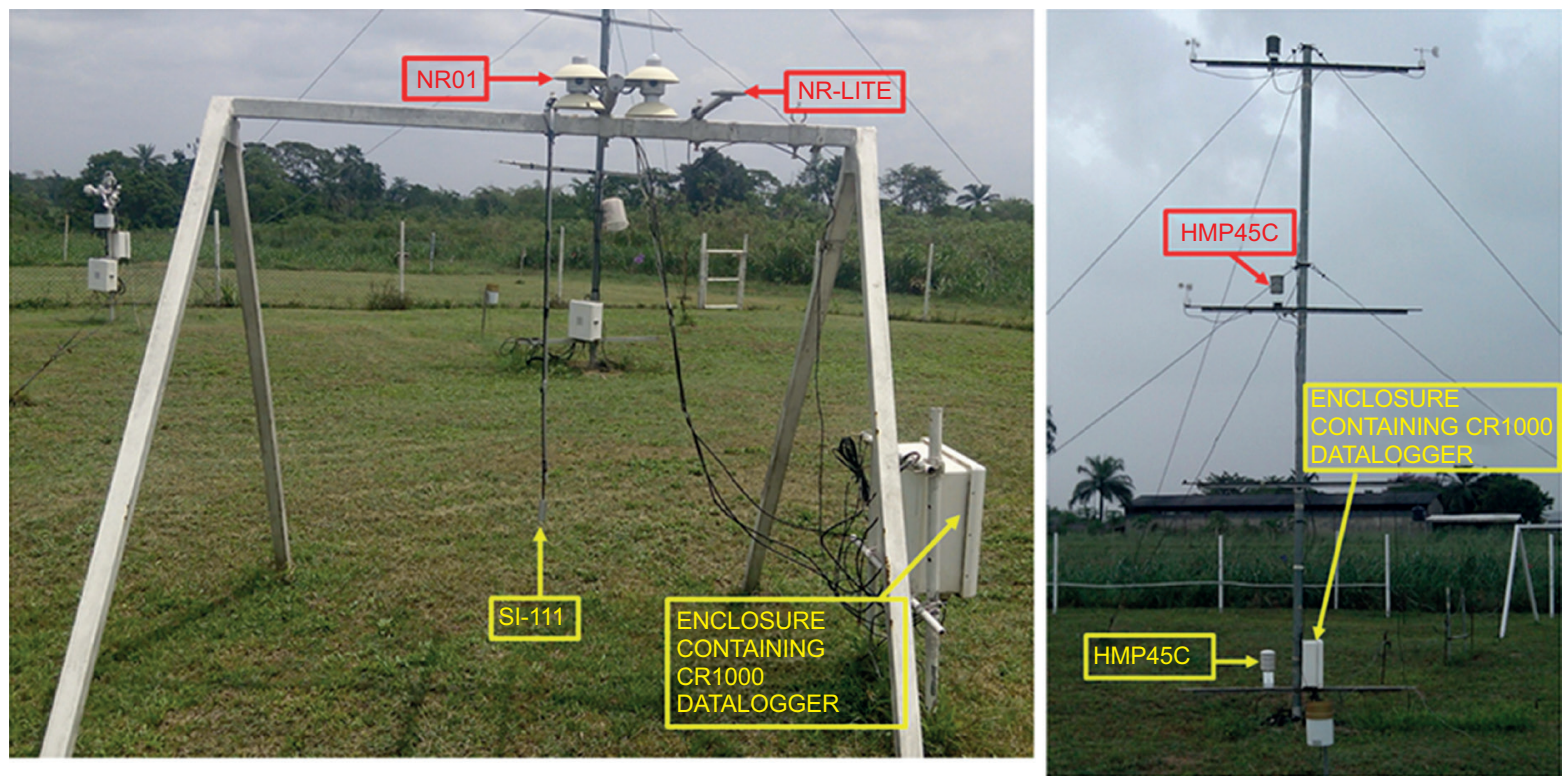

Fig. 1. Arrangements of the sensors at the meteorological site, Obafemi Awolowo University, Ile-Ife, Nigeria.

between 1000 and $1500 \mathrm{~mm}$ with weak surface wind flow less than $1.5 \mathrm{~ms}^{-1}$ (Hayward and Oguntoyinbo, 1987; Ayoola et al., 2014; Soneye et al., 2019). At Ile-Ife, the intensity of global solar radiation received at the surface is high all year-round, with maximum values of $1100 \mathrm{Wm}^{-2}$ (at 13:00 LT) for March, and $800 \mathrm{Wm}^{-2}$ (at 13:00 LT) for August (Balogun et al., 2003).

The data used for this study were measured from January 2016 to December 2017. The downward longwave radiation flux at the site was measured using an IR01 pyrgeometer of spectral response between 4.5 and $50 \mu \mathrm{m}$. The incoming solar radiation flux was measured with a SR01 pyranometer of spectral range between 0.3-2.8 $\mu \mathrm{m}$. IR01 and SR01 sensors are contained in the four-component net radiometer (model NR01, Hukseflux, USA) installed at a height of $1.75 \mathrm{~m}$ above the ground surface (Fig. 1). The sensitivity of the net radiometer ranges from 8.2 to $15.7 \mu \mathrm{V} / \mathrm{Wm}^{-2}$ with a field view of $180^{\circ}$. Air temperature and relative humidity were measured using a Vaisala HMP45C probe (Campbell Scientific, USA) installed at a 2-m height (Fig. 1). The temperature sensor has an accuracy of $\pm 0.05{ }^{\circ} \mathrm{C}$. The relative humidity sensor has an accuracy at $20{ }^{\circ} \mathrm{C} \pm 2 \%(0$ to $90 \%$ relative humidity) and $\pm 3 \%$ relative humidity (90 to $100 \%$ relative humidity). The calibration constants of the net radiometer and Vaisala probe provided by the manufacturer were used. All the sensors were recalibrated before and after measurements and no significant drift was observed in the calibration constants of the instruments after the measurement period (Soneye, 2018; Soneye et al., 2019). In this study, the cleaning of all the sensors was performed on a regular basis by cleaning their lenses and domes gently with a moistened cotton swab dipped in distilled water and alcohol to avoid the scratching of the thin optical coating on the window. The radiation shield of HMP45C was checked monthly to ensure that the radiation shield was free from debris and dust. Regarding the NR01 sensor, the interior of the dome was carefully inspected to ensure that there was no condensation, and the sensor inversion test was carried out. This sensor inversion test is a recommendation from the sensors' manufacturer, and it involves the inversion of the position of the sensor (a $180^{\circ}$ turn) and the checking of the output signals, which must be of the same magnitude but with a reversed sign ( + to - and - to + ). For best results, this test was done on a clear day around noon when the sun was high in the sky for the pyranometers and on a clear night for the pyrgeometers. Furthermore, the cables of all the sensors were checked at regular intervals for crackings. The data was acquired using 
Campbell Scientific CR1000 dataloggers with sampling rate of $10 \mathrm{~s}$ and storage time of $1 \mathrm{~min}$ for further processing (Fig. 1).

\subsection{Proposed model under cloudless sky conditions} An equation for estimating downward longwave radiation under cloudless sky condition (Eq. [12S] in the supplementary material) was proposed.

\subsubsection{Evaluation method}

The downward longwave radiation models under cloudless sky conditions defined in Table I were evaluated. Firstly, the downward longwave radiation models with their original coefficients were tested against the measured data. Secondly, the experimental coefficients estimated at local conditions from the models were tested against the measured data. A dataset of 34560 measurements with cloud amount $\leq 0.1$, clearness index $\leq 0.13$, high air temperature between 30 and $38^{\circ} \mathrm{C}$ and low relative humidity between 20 and $40 \%$ was used for the study. The cloud amount was determined using Eq. (S1) in the supplementary materials, which was proposed by Jegede et al. (2006). The dataset was separated randomly into two equal parts. The first half of the dataset (17 280 data) was used to test the models while the second half (17 280 data) was used to calibrate the models. The accuracies and performances of all the models before and after calibration were assessed using the statistical errors listed in Eqs. (S3) to (S11) in the supplementary materials. The calibration was done using a nonlinear least square fit to adjust the original coefficients of the models.

\section{Results and discussion}

The diurnal variation of clear-sky downward longwave radiation measured and estimated using original coefficients of the models is shown in Figure 2. From the time series plots, the peak values of both measured and estimated downward longwave radiation are observed to be in the late afternoon periods (usually between 15:00 and 17:00 LT) while lower values were recorded at nighttime and early morning. The values of the measured and estimated longwave radiation flux are low throughout the late evening and morning (around 21:00 to about 08:00 LT). In Figure 2 it can be seen that daytime values reach a maximum of $436 \mathrm{Wm}^{-2}$ at 16:00 LT while the estimated values from the models reach maximum values between 378 and $505 \mathrm{Wm}^{-2}$. The Swinbank (1963), Idso and Jackson (1969), Deacon (1970) and Prata (1996)

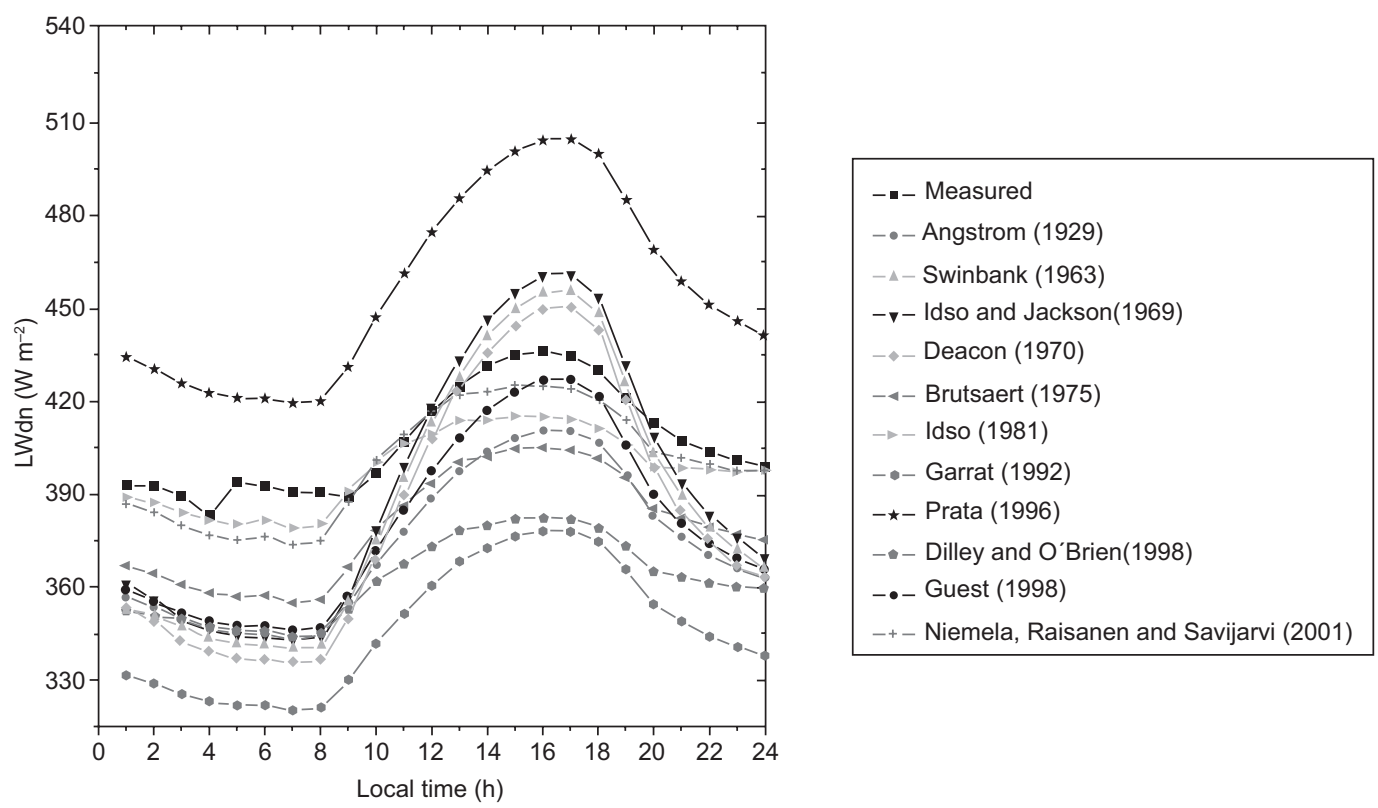

Fig. 2. Variations of the clear-sky downward longwave radiation flux (LWdn), both measured and estimated using the original coefficients of the models. 
models gave the maximum values of about 456 , 461, 450 and $505 \mathrm{Wm}^{-2}$, respectively, during daytime at 16:00 and 17:00 LT. The Ångström (1929), Brutsaert (1975), Idso (1981), Garratt (1992), Dilley and O'Brien (1998), Guest (1998), and Niemela et al. (2001) models underestimated the downward longwave radiation flux with maximum values of 411 , $405,415,378,382,427$ and $425 \mathrm{Wm}^{-2}$, respectively, at 15:00, 16:00 and 17:00 LT. It was observed that the values obtained tfrom Idso (1981) and Niemela et al. (2001) models were lower and closer to the measured values. The differences in values of the downward longwave radiation estimated from all the models and direct measurements are because the coefficient of each empirical model is site-specific due to variations in the water vapor pressure and air temperature, which ensue from the temporal and spatial variations in atmospheric circulation and land use patterns, respectively (Dale, 1997; Kessler and Jaeger, 1999; Alaa et al., 2017).

The linear regression of downward longwave radiation flux between measured and estimated values using the original coefficient is presented in Figure 3, while the performances of the models compared to measured data is presented in Table II. The analysis was done for quantitative evaluation of all the models with respect to the measured data. It was observed that the original Swinbank (1963), Idso and Jackson (1969), Deacon (1970), and Prata (1996) models overestimated the flux (Fig. 3). The overestimation of the flux by these models is affirmed by the high values of errors $\left(\mathrm{MBE} \sim 49 \mathrm{Wm}^{-2}\right.$, RMBE $\sim 12 \%$, $\mathrm{RMSE} \sim 52 \mathrm{Wm}^{-2}, \mathrm{RRMSE} \sim 13 \%, \mathrm{MAE} \sim 49 \mathrm{Wm}^{-2}$, RMAE $\sim 12 \%$ ) obtained when compared to the other models. The low values obtained for the correlation coefficient and coefficient of determination of these models $(\sim 0.82$ and $\sim 0.68$, respectively) indicate greater deviation and worse agreement between the values estimated from the models and the measured data. On the other hand, the original Ångström (1929), Brutsaert (1975), Garratt (1992), Dilley and O'Brien (1998), and Guest (1998) models were observed to underestimate the flux. The best results were obtained with the Idso (1981) and Niemela et al. (2001) models with low values of errors and higher values of the index of agreement ( $d$ [see Eq. S11 in the supplementary materials]) closer to the unity, which show good agreement between the estimated values and the experimental data. The under/overestimation of the downward longwave radiation flux by the models can be attributed to the assumption of atmospheric humidity as an implicit function of ambient temperature based on the strong correlation between water vapor pressure and air temperature by all the models (Iziomon et al., 2003). Also, the under/overestimation of the downward longwave radiation flux by the models when compared to measured values at the study site can be attributed to the differences between geographical location, cloud formation, precipitation, atmospheric turbulence and pollution levels of Ile-Ife and the various sites where all the models' coefficients were developed (Sozzi et al., 1999; Alaa et al., 2017).

The statistical results obtained in this study compared to those reported by other authors that used the same methods is presented in Table III, where it is shown that the statistical results obtained by other authors were developed under different weather conditions from the tropical climate where this study was conducted. From the table it can be seen that the Ångström (1929), Idso and Jackson (1969), Brutsaert (1975), Prata (1996), and Dilley and O’Brien (1998) models performed better than other models despite the different weather conditions of the regions where each measurement site was located. Comparing the results in Table II with those listed in Table III, the values of the coefficient of determination obtained in this study are comparable with the range of values reported for the same type of models by Santos et al. (2011) and Alaa etal. (2017). The values of $\mathrm{R}^{2}$ and RMSE obtained for both Idso and Jackson (1969) and Prata (1996) and Swinbank (1963) are similar to those obtained by Iziomon et al. (2003), Duarte et al. (2006), Bilbao and de Miguel (2007), Lhomme et al. (2007), Alados et al. (2011), Carmona et al. (2014), and Guo et al. (2018).

Table IV shows the original and calibrated coefficient values for all the models, which generally were significantly different from the original values except for the Swinbank (1963), Brutsaert (1975), and Guest (1998) models. Percentage differences of about $11 \%$ between the calibrated and original coefficients were obtained for Ångström (1929), Idso (1981), and Niemela et al. (2001) models. Hence, to improve the performances of all the models, it is very crucial to calibrate their original coefficients. The results obtained for coefficients $a_{5}$ and $b_{5}$ for the 

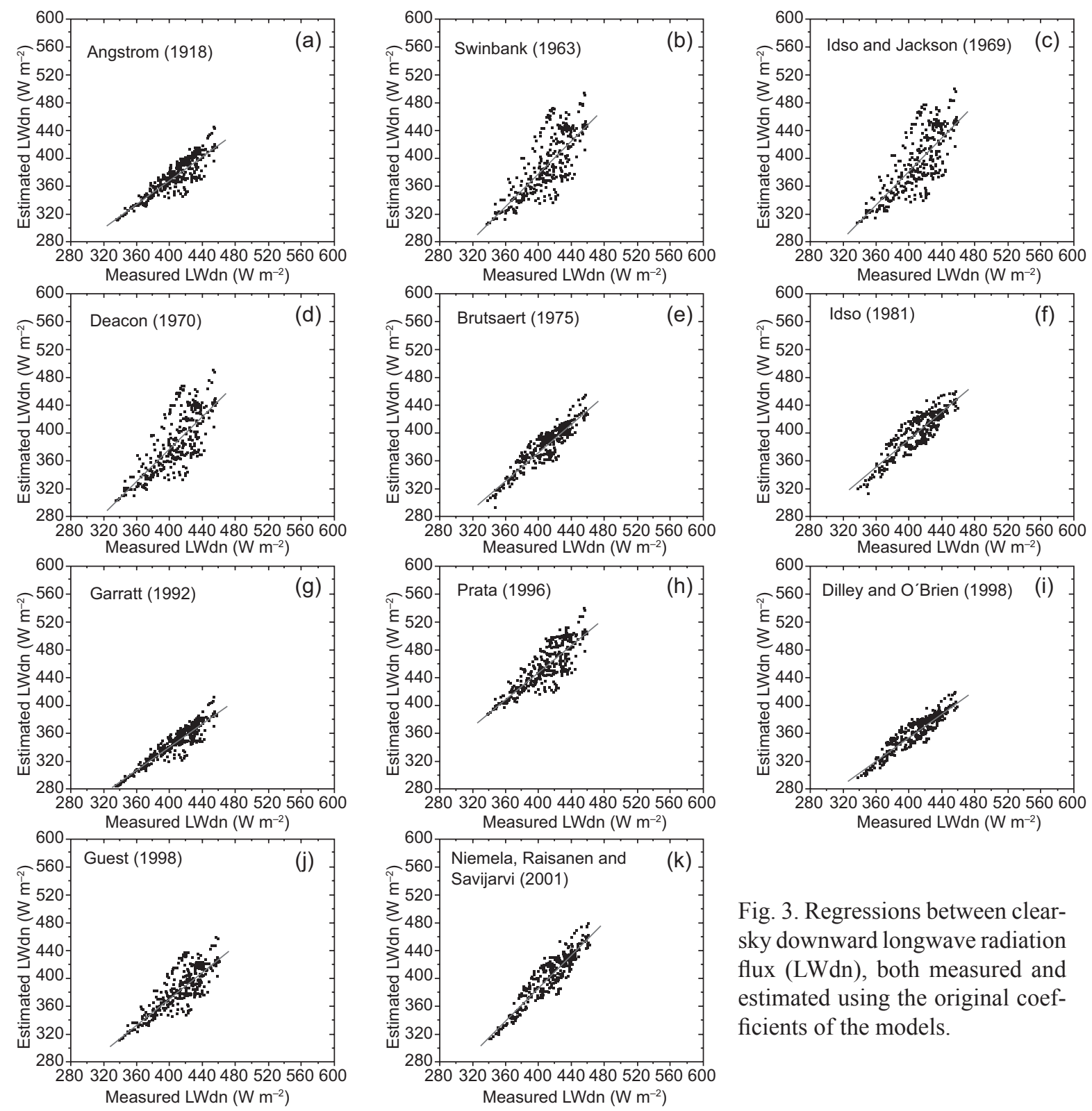

Fig. 3. Regressions between clearsky downward longwave radiation flux (LWdn), both measured and estimated using the original coefficients of the models.

Brutsaert (1975) model are similar to those reported by Carmona et al. (2014).

The statistical results of the calibrated models, and the accuracy of the models before and after calibration are presented in Table V and Figure 4, respectively. The results show that the locally calibrated models performed better than the original models (Table V and Fig. 4). As presented in Table V, the values of all statistical errors for the calibrated models were greatly reduced. The highest values of statistical errors were obtained from the models that use only air temperature (calibrated Swinbank [1963], Idso and Jackson [1969], and Deacon [1970]) despite the increase in the values of their correlation coefficient $\left(\mathrm{R}^{2} \sim 0.71\right)$ and decrease in errors (Table V, Fig. 4) when compared to the original models $\left(\mathrm{R}^{2}=0.57\right)$. This implies that the accuracies and performances of these models are worse than the other models, which is in agreement with the results obtained by Kjaersgaard et al. (2007), Kruk et al. (2010), Carmona et al. (2014), and Guo et al., 2018. Based on the results listed in Table $\mathrm{V}$, the performances of all the 
Table II. Statistical results of downward longwave radiation models using their original coefficients.

\begin{tabular}{lccccccccc}
\hline Models & $\mathrm{R}$ & $\mathrm{R}^{2}$ & $\begin{array}{c}\mathrm{MBE} \\
\left(\mathrm{Wm}^{-2}\right)\end{array}$ & $\begin{array}{c}\mathrm{RMBE} \\
(\%)\end{array}$ & $\begin{array}{c}\mathrm{RMSE} \\
\left(\mathrm{Wm}^{-2}\right)\end{array}$ & $\begin{array}{r}\mathrm{RRMSE} \\
(\%)\end{array}$ & $\begin{array}{c}\mathrm{MAE} \\
\left(\mathrm{Wm}^{-2}\right)\end{array}$ & $\begin{array}{c}\mathrm{RMAE} \\
(\%)\end{array}$ & $d$ \\
\hline Angström (1918) & 0.88 & 0.77 & -33.49 & -8.22 & 36.09 & 8.86 & 33.49 & 8.22 & 0.71 \\
Swinbank (1963) & 0.76 & 0.57 & -18.95 & -4.65 & 34.48 & 8.47 & 29.26 & 7.18 & 0.77 \\
Idso and Jackson (1969) & 0.76 & 0.57 & -15.08 & -3.70 & 33.37 & 8.19 & 28.17 & 6.92 & 0.79 \\
Deacon (1970) & 0.76 & 0.57 & -23.78 & -5.84 & 37.14 & 9.12 & 31.78 & 7.80 & 0.75 \\
Brutsaert (1975) & 0.92 & 0.85 & -27.50 & -6.75 & 29.96 & 7.35 & 27.45 & 6.75 & 0.79 \\
Idso (1981) & 0.89 & 0.81 & -9.33 & -2.29 & 16.78 & 4.12 & 14.43 & 3.54 & 0.92 \\
Garratt (1992) & 0.91 & 0.84 & -60.65 & -14.89 & 61.68 & 15.14 & 60.66 & 14.89 & 0.53 \\
Prata (1996) & 0.82 & 0.68 & 49.02 & 12.03 & 52.38 & 12.86 & 49.02 & 12.03 & 0.57 \\
Dilley and O'Brien (1998) & 0.93 & 0.86 & -44.92 & -11.03 & 46.12 & 11.32 & 44.92 & 11.03 & 0.63 \\
Guest (1998) & 0.83 & 0.68 & -27.04 & -6.64 & 32.39 & 7.95 & 28.59 & 7.02 & 0.76 \\
Niemela et al. (2001) & 0.92 & 0.85 & -7.43 & -1.82 & 16.46 & 4.04 & 13.65 & 3.35 & 0.93 \\
\hline
\end{tabular}

$d$ : index of agreement.

Table III. Statistical results of clear-sky downward longwave radiation models reported by other authors.

\begin{tabular}{|c|c|c|c|c|c|}
\hline Models/authors* & $\begin{array}{c}a \\
\left(\mathrm{Wm}^{-2}\right)\end{array}$ & $b$ & $\mathrm{R}^{2}$ & $\begin{array}{c}\mathrm{MBE} \\
\left(\mathrm{Wm}^{-2}\right)\end{array}$ & $\begin{array}{l}\text { RMSE } \\
\left(\mathrm{Wm}^{-2}\right)\end{array}$ \\
\hline \multicolumn{6}{|l|}{ Ångström (1918) } \\
\hline Niemala et al. (2001) & - & - & - & $-0.1 /-18.2$ & $8.7 / 24.3$ \\
\hline \multicolumn{6}{|l|}{ Swinbank (1963) } \\
\hline Niemala et al. (2001) & - & - & - & $-16.8 /-34.8$ & $19.0 / 54.3$ \\
\hline Iziomon et al. (2003) & - & - & - & $-23 / 26$ & $40 / 40$ \\
\hline Duarte et al. (2006) & 1.133 & -17 & 0.91 & 24 & 29 \\
\hline Bilbao and de Miguel (2007) & - & - & - & 32 & 40 \\
\hline Lhomme et al. (2007) & - & - & - & 59 & 64 \\
\hline Santos et al. (2011) & - & - & 0.79 & 13.1 & 22.0 \\
\hline Carmona et al. (2014) & 22 & 1.02 & 0.78 & 30 & 40 \\
\hline Alaa et al. (2017) & - & - & 0.78 & 16.6 & 26.0 \\
\hline Guo et al. (2018) & - & - & 0.83 & 7.72 & 36.65 \\
\hline \multicolumn{6}{|l|}{ Idso and Jackson (1969) } \\
\hline Iziomon et al. (2003) & - & - & - & $-13 / 3$ & $40 / 50$ \\
\hline Duarte et al. (2006) & 1.141 & -17 & 0.91 & 27 & 31 \\
\hline Choi et al. (2008) & - & - & 0.84 & 10 & 26 \\
\hline Alados et al. (2011) & - & - & 0.77 & 25 & 35 \\
\hline Santos et al. (2011) & - & & 0.79 & 15.2 & 25.1 \\
\hline Carmona et al. (2014) & 22 & 1.03 & 0.78 & 30 & 40 \\
\hline Alaa et al. (2017) & - & - & 0.78 & 18.2 & 28.3 \\
\hline Guo et al. (2018) & - & - & 0.83 & 15.99 & 36.31 \\
\hline \multicolumn{6}{|l|}{ Brutsaert (1975) } \\
\hline Niemala et al. (2001) & - & - & - & $-11.1 /-42.6$ & $14.3 / 47.4$ \\
\hline Iziomon et al. (2003) & - & - & $0.78 / 0.55$ & $-19 / 20$ & $30 / 30$ \\
\hline Duarte et al. (2006) & 0.903 & 43 & 0.96 & 13 & 15 \\
\hline
\end{tabular}

$a$ : intercept; $b$ : slope. 
Table III. Statistical results of clear-sky downward longwave radiation models reported by other authors.

\begin{tabular}{|c|c|c|c|c|c|}
\hline Models/authors* & $\begin{array}{c}a \\
\left(\mathrm{Wm}^{-2}\right)\end{array}$ & $b$ & $\mathrm{R}^{2}$ & $\begin{array}{c}\mathrm{MBE} \\
\left(\mathrm{Wm}^{-2}\right)\end{array}$ & $\begin{array}{c}\text { RMSE } \\
\left(\mathrm{Wm}^{-2}\right)\end{array}$ \\
\hline Bilbao and de Miguel (2007) & - & - & - & 16 & 20 \\
\hline Lhomme et al. (2007) & - & - & - & 12 & 15 \\
\hline Choi et al. (2008) & - & - & 0.87 & 8 & 14 \\
\hline Alados et al. (2011) & - & - & 0.89 & 4 & 15 \\
\hline Santos et al. (2011) & - & - & 0.87 & 3.9 & 7.7 \\
\hline Carmona et al. (2014) & 14 & 1.00 & 0.89 & 15 & 20 \\
\hline Alaa et al. (2017) & - & - & 0.84 & 4.7 & 9.9 \\
\hline Guo et al. (2018) & - & - & 0.91 & 5.77 & 26.5 \\
\hline \multicolumn{6}{|l|}{ Idso (1981) } \\
\hline Niemala et al. (2001) & - & - & - & $9.2 /-8.3$ & $12.6 / 17.7$ \\
\hline Duarte et al. (2006) & 0.830 & 81 & 0.96 & 29 & 31 \\
\hline Bilbao and de Miguel (2007) & - & - & - & 30 & 32 \\
\hline Lhomme et al. (2007) & - & - & - & 47 & 50 \\
\hline Santos et al. (2011) & - & - & 0.77 & 8.1 & 14.1 \\
\hline Carmona et al. (2014) & 50 & 0.94 & 0.88 & 30 & 30 \\
\hline Alaa et al. (2017) & - & - & 0.77 & 11.1 & 17.3 \\
\hline Guo et al. (2018) & - & - & 0.92 & 15.82 & 28.19 \\
\hline \multicolumn{6}{|l|}{ Prata (1996) } \\
\hline Niemala et al. (2001) & - & - & - & $-5.0 /-17.5$ & $9.8 / 22.8$ \\
\hline Duarte et al. (2006) & 0.869 & 57 & 0.96 & 17 & 19 \\
\hline Lhomme et al. (2007) & - & - & - & 37 & 40 \\
\hline Choi et al. (2008) & - & - & 0.87 & 17 & 16 \\
\hline Alados et al. (2011) & - & - & 0.89 & 9 & 16 \\
\hline Santos et al. (2011) & - & - & 0.88 & 3.6 & 7.3 \\
\hline Carmona et al. (2014) & 40 & 0.92 & 0.89 & 20 & 23 \\
\hline Guo et al. (2018) & - & - & 0.92 & 2.05 & 22.41 \\
\hline \multicolumn{6}{|l|}{ Dilley and O'Brien (1998) } \\
\hline Niemala et al. (2001) & - & - & - & $-7.1 /-19.4$ & $11.2 / 23.8$ \\
\hline
\end{tabular}

$a$ : intercept; $b$ : slope.

*Measurement sites and periods:

Niemela et al. (2001): Sodankyla, Finland, summer/winter 1997.

Iziomon et al. (2003): Bremgarten (lowland)/Feldberg (Mountain), Germany, 1991-1996.

Duarte et al. (2006): Ponta Grossa (humid region, subtropical climate), Brazil, 2003-2004.

Bilbao and de Miguel (2007): Valladolid (Mediterranean continental climate), Spain, 2001-2004.

Lhomme et al. (2007): Condori (Andean Altiplano), Bolivia, 2005.

Choi et al. (2008): Florida (humid region, subtropical climate), USA, 2004-2005.

Alados et al. (2011): Tabernas, Almería (semiarid climate), Spain, 2002.

Santos et al. (2011): Ceará State (semiarid climate), Brazil, 2005-2006.

Carmona et al. (2014): Tandil (sub-humid), Argentina, 2007-2010.

Alaa et al. (2017): Baghdad, (semi-arid/ subtropical climate), Iraq, 2014-2015.

Guo et al. (2018): 71 globally distributed sites, 2000-2006. 
Table IV. Comparison of original/local and calibrated coefficient values for the 11 downward longwave radiation models under cloudless sky condition.

\begin{tabular}{|c|c|c|c|c|}
\hline Model & Coefficients & Original coefficients & Calibrated coefficients & Relative difference $(\%)$ \\
\hline Ångström (1929) & $\begin{array}{l}a_{1} \\
b_{1}\end{array}$ & $\begin{array}{c}0.83 \\
0.18 \times 10^{-0.067}\end{array}$ & $\begin{array}{c}0.9176 \\
0.3355 \times 10^{-0.067}\end{array}$ & 11 \\
\hline Swinbank (1963) & $a_{2}$ & $0.94 \times 10^{-5}$ & $0.977410^{-5}$ & 4 \\
\hline $\begin{array}{l}\text { Idso and Jackson } \\
\text { (1969) }\end{array}$ & $\begin{array}{l}a_{3} \\
b_{3}\end{array}$ & $\begin{array}{c}0.261 \\
-7.77 \times 10^{-4}\end{array}$ & $\begin{array}{c}0.0573 \\
-7.9073 \times 10^{-6}\end{array}$ & $\begin{array}{l}-78 \\
-89\end{array}$ \\
\hline Deacon (1970) & $\begin{array}{l}a_{4} \\
b_{4}\end{array}$ & $\begin{array}{c}0.94 \times 10^{-5} \\
0.035\end{array}$ & $\begin{array}{c}-6.0931 \times 10^{-6} \\
-4.7882\end{array}$ & $\begin{array}{c}-165 \\
-13781\end{array}$ \\
\hline Brutsaert (1975) & $\begin{array}{l}a_{5} \\
b_{5}\end{array}$ & $\begin{array}{c}1.24 \\
0.143\end{array}$ & $\begin{array}{l}1.1833 \\
0.1014\end{array}$ & $\begin{array}{l}-5 \\
-29\end{array}$ \\
\hline Idso (1981) & $\begin{array}{l}a_{6} \\
b_{6}\end{array}$ & $\begin{array}{c}0.7 \\
5.95 \times 10^{-5}\end{array}$ & $\begin{array}{c}0.7795 \\
3.8700 \times 10^{-5}\end{array}$ & $\begin{array}{c}11 \\
-35\end{array}$ \\
\hline Garratt (1992) & $\begin{array}{l}a_{7} \\
b_{7}\end{array}$ & $\begin{array}{c}0.79 \\
0.174 \\
\end{array}$ & $\begin{array}{l}0.9408 \\
0.2632 \\
\end{array}$ & $\begin{array}{l}19 \\
51 \\
\end{array}$ \\
\hline Prata (1996) & $\begin{array}{l}a_{8} \\
b_{8}\end{array}$ & $\begin{array}{c}1.2 \\
3 \\
\end{array}$ & $\begin{array}{l}1.8097 \\
0.5025 \\
\end{array}$ & $\begin{array}{c}51 \\
-83 \\
\end{array}$ \\
\hline $\begin{array}{l}\text { Dilley and O'Brien } \\
\text { (1998) }\end{array}$ & $\begin{array}{l}a_{9} \\
b_{9} \\
c_{9}\end{array}$ & $\begin{array}{l}59.38 \\
113.7 \\
96.96\end{array}$ & $\begin{array}{c}89.1642 \\
130.9419 \\
83.1233\end{array}$ & $\begin{array}{c}50 \\
15 \\
-14 \\
\end{array}$ \\
\hline Guest (1998) & $\begin{array}{l}a_{10} \\
b_{10} \\
c_{10} \\
\end{array}$ & $\begin{array}{c}1.0438 \\
0.2486 \\
113.6 \\
\end{array}$ & $\begin{array}{c}1.0983 \\
0.8933 \\
147.6721 \\
\end{array}$ & $\begin{array}{c}5 \\
259 \\
30 \\
\end{array}$ \\
\hline Niemela et al. (2001) & $\begin{array}{l}a_{11} \\
b_{11}\end{array}$ & $\begin{array}{c}0.72 \\
0.009\end{array}$ & $\begin{array}{l}0.7888 \\
0.0059\end{array}$ & $\begin{array}{c}10 \\
-35\end{array}$ \\
\hline
\end{tabular}

Table V. Statistical results of downward longwave radiation models using their calibrated coefficients.

\begin{tabular}{lccccccccc}
\hline Model & $\mathrm{R}$ & $\mathrm{R}^{2}$ & $\begin{array}{c}\mathrm{MBE} \\
\left(\mathrm{Wm}^{-2}\right)\end{array}$ & $\begin{array}{c}\mathrm{RMBE} \\
(\%)\end{array}$ & $\begin{array}{c}\text { RMSE } \\
\left(\mathrm{Wm}^{-2}\right)\end{array}$ & $\begin{array}{c}\text { RRMSE } \\
(\%)\end{array}$ & $\begin{array}{c}\text { MAE } \\
\left(\mathrm{Wm}^{-2}\right)\end{array}$ & $\begin{array}{c}\text { RMAE } \\
(\%)\end{array}$ & $d$ \\
\hline Angström (1918) & 0.85 & 0.72 & -1.03 & -0.24 & 15.01 & 3.43 & 11.97 & 2.74 & 0.88 \\
Swinbank (1963) & 0.84 & 0.70 & -6.20 & -1.42 & 29.80 & 6.81 & 25.58 & 5.85 & 0.74 \\
Idso and Jackson (1969) & 0.84 & 0.71 & -18.17 & -4.15 & 20.58 & 4.71 & 18.18 & 4.16 & 0.72 \\
Deacon (1970) & 0.84 & 0.71 & -17.87 & -4.09 & 20.54 & 4.70 & 17.87 & 4.09 & 0.74 \\
Brutsaert (1975) & 0.86 & 0.73 & 4.45 & 1.02 & 12.81 & 2.93 & 10.85 & 2.48 & 0.89 \\
Idso (1981) & 0.85 & 0.73 & 4.94 & 1.13 & 10.50 & 2.40 & 8.70 & 1.99 & 0.90 \\
Garratt (1992) & 0.85 & 0.73 & 2.24 & 0.51 & 13.93 & 3.19 & 11.39 & 2.60 & 0.89 \\
Prata (1996) & 0.86 & 0.73 & 4.90 & 1.12 & 12.83 & 2.93 & 10.93 & 2.50 & 0.89 \\
Dilley and O'Brien (1998) & 0.86 & 0.73 & 2.49 & 0.59 & 9.78 & 2.24 & 8.07 & 1.85 & 0.92 \\
Guest (1998) & 0.85 & 0.71 & 0.65 & 0.15 & 9.38 & 2.14 & 7.84 & 1.79 & 0.91 \\
Niemela et al. (2001) & 0.86 & 0.73 & 8.62 & 1.97 & 14.05 & 3.21 & 12.14 & 2.78 & 0.87 \\
\hline
\end{tabular}

$d$ : index of agreement. 

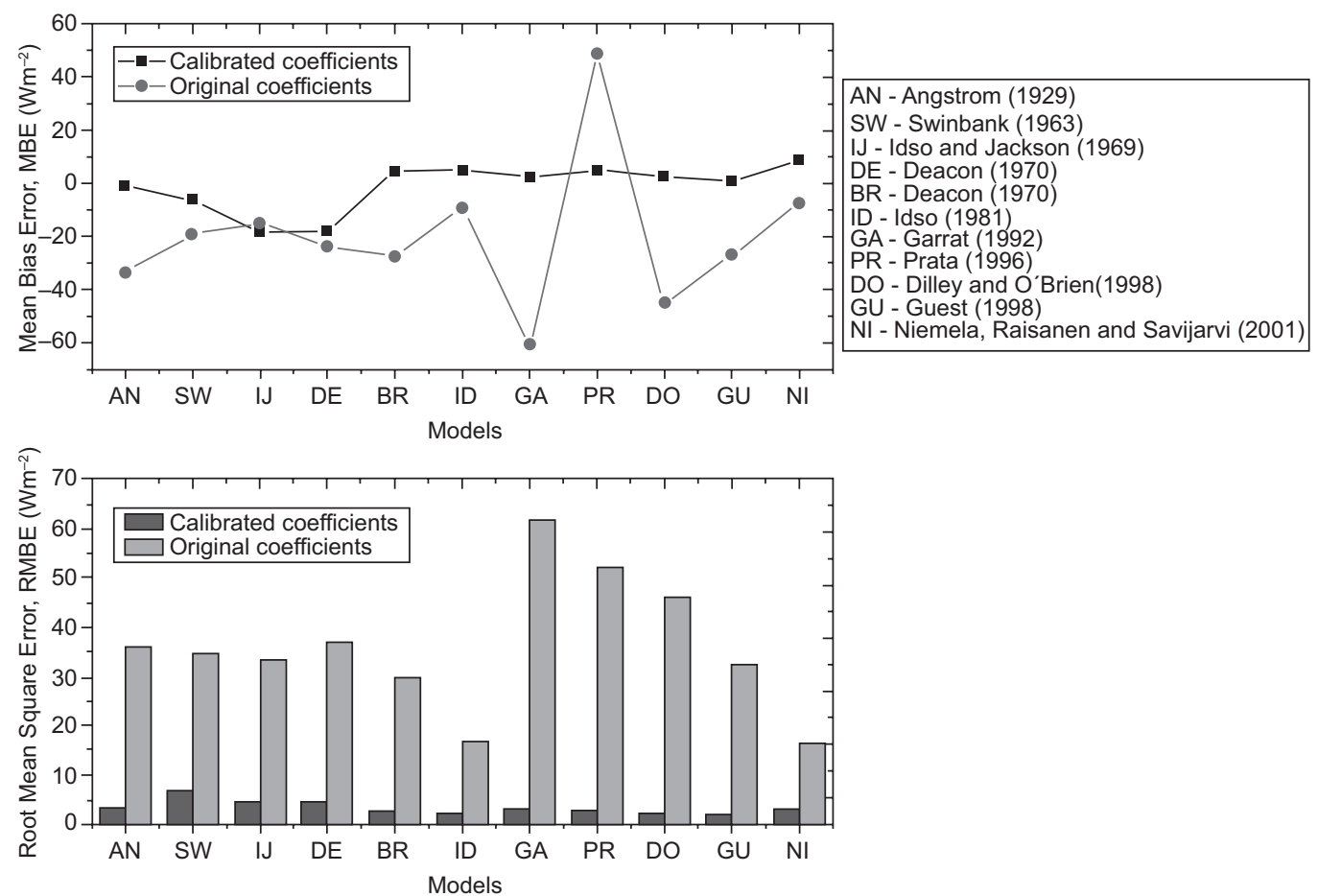

Fig. 4. Statistical measures for the downward longwave radiation flux estimated from the models before and after calibration at Ile-Ife, Nigeria.

models are ranked as follows: Guest (1998), Dilley and O’Brien (1998), Idso (1981), Prata (1996), Brutsaert (1975), Garratt (1992), Niemela et al. (2001), Ångström (1929), Idso and Jackson (1969), Deacon (1970), and Swinbank (1963).

Furthermore, the equation proposed in this study for estimating downward longwave radiation under cloudless sky conditions is expressed in Eq. (S13) in the supplementary materials. The linear regression between the downward longwave radiation flux estimated using Eq. (S13) and the measured flux is presented in Figure 5b. Also, the results of the statistical errors used to validate the proposed model and those of the best model previously tested are presented in Table VI. As shown in Figure 5a, a maximum value of about $432 \mathrm{Wm}^{-2}$ at 17:00 LT and $434 \mathrm{Wm}^{-2}$ at 16:00 LT were observed for the measured and estimated downward longwave radiation flux, respectively. The variations of the estimated values of the downward longwave radiation at midnight and early morning are slightly higher than the measured values. The estimated values obtained from the proposed model were observed to somehow underestimate the flux between 10:00 and 14:00 LT, and afterwards overestimate the flux until around 20:00 LT, when it coincides with the measured value. The high values of

Table VI. Statistical results of the proposed downward longwave radiation model and the Guest (1998) model.

\begin{tabular}{lccccccccc}
\hline Model & $\mathrm{R}$ & $\mathrm{R}^{2}$ & $\begin{array}{c}\mathrm{MBE} \\
\left(\mathrm{Wm}^{-2}\right)\end{array}$ & $\begin{array}{c}\mathrm{RMBE} \\
(\%)\end{array}$ & $\begin{array}{c}\text { RMSE } \\
\left(\mathrm{Wm}^{-2}\right)\end{array}$ & $\begin{array}{c}\text { RRMSE } \\
(\%)\end{array}$ & $\begin{array}{c}\text { MAE } \\
\left(\mathrm{Wm}^{-2}\right)\end{array}$ & $\begin{array}{c}\text { RMAE } \\
(\%)\end{array}$ & $d$ \\
\hline Proposed model & 0.94 & 0.88 & -0.17 & -0.04 & 9.22 & 2.23 & 7.44 & 1.02 & 0.97 \\
Guest (1998) & 0.85 & 0.71 & 0.65 & 0.15 & 9.38 & 2.14 & 7.84 & 1.79 & 0.91 \\
\hline
\end{tabular}

$d$ : index of agreement. 


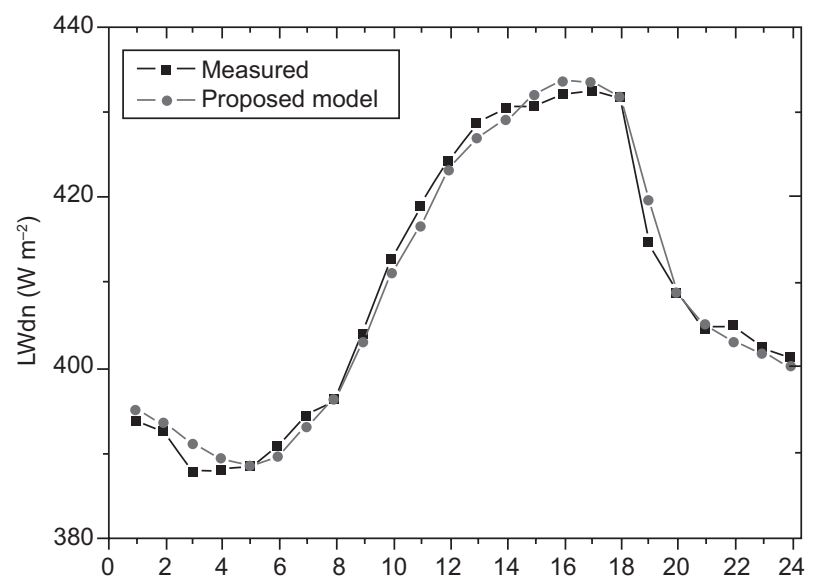

(a)

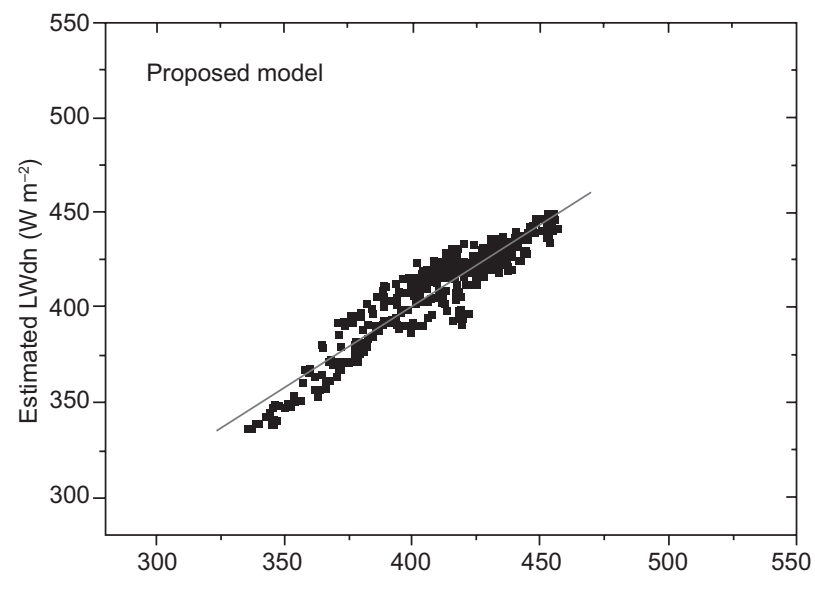

(b)

Measured LWdn $\left(\mathrm{W} \mathrm{n}^{-2}\right)$

Fig. 5. (a) Diurnal variation of the clear-sky downward longwave radiation flux (LWdn), both measured and estimated from the proposed model; (b) regression between clear-sky downward longwave radiation flux (LWdn), both measured and estimated from the proposed model: $C_{A}=\frac{S_{\downarrow M}}{S_{\downarrow} c}\left\{\begin{array}{cc}S_{o} \tau_{K} \sin \Psi, & \Psi>0 \\ 0 & , \quad\end{array}<L_{\downarrow C l}=\left[d\left(\frac{e_{0}}{T_{A}}\right)^{g}\right] \sigma T_{A}^{4} L_{\downarrow C l}=\left[10.64\left(\frac{e_{0}}{T_{A}}\right)^{0.053}\right] \sigma T_{A}^{4}\right.$

0.93 and 0.88 obtained for the correlation coefficient and coefficient of determination, respectively, indicate great conformity and good agreement between the values estimated from the proposed model and the measured data. The results show that the performance of the proposed model is better than the performance of the all the calibrated models.

\section{Conclusions}

Data on downward longwave radiation (long-term) are still scarce, especially in tropical regions. Most of the available empirical downward longwave radiation models were developed in areas with different climatic conditions than those of tropical regions, which is why this study evaluates and calibrates 11 existing downward longwave radiation models for clear sky conditions using meteorological data measured at Ile-Ife, Nigeria. A model for estimating clear-sky downward longwave radiation was proposed. The major conclusions derived from this study are:

a. The original Swinbank (1963), Idso and Jackson (1969), Deacon (1970), and Prata (1996) models overestimated the flux, while the Ångström (1929), Brutsaert (1975), Garratt (1992), Dilley and O'Brien (1998), and Guest (1998) models underestimated it. b. The best results were obtained from the original Idso (1981) and Niemela et al. (2001) models, with RMBE, RMAE and RRMSE less than $5.0 \%$.

c. The performances and accuracies of all the models showed significant improvement after calibration.

d. The accuracies and performances of calibrated Swinbank (1963), Idso and Jackson (1969), and Deacon (1970) models, which use only air temperature as input are worse than the other models. This confirmed that other meteorological parameters such as relative humidity, precipitable water content and water vapor pressure are very important for estimating the flux under cloudless sky conditions.

e. The calibrated Guest (1998) model, which had low errors $\left(\mathrm{MBE}=0.65 \mathrm{Wm}^{-2}, \mathrm{RMBE}=0.15 \%\right.$, $\mathrm{RMSE}=9.38 \mathrm{Wm}^{-2}, \mathrm{RRMSE}=2.14 \%$, MAE $=7.84 \mathrm{Wm}^{-2}$, RMAE $=1.79$ ) performed best, followed by the Dilley and O'Brien (1998), Idso (1981), Prata (1996), Brutsaert (1975), Garratt (1992), Niemela et al. (2001), Ångström (1929), Idso and Jackson (1969), Deacon (1970), and Swinbank (1963) models.

f. The proposed model had a better performance, with low statistical errors, than all the existing empirical models tested, and had a good agreement $\left(\mathrm{R}^{2}=0.88\right)$ with the measured data. This 
implies that calibrating the coefficients of models developed locally is very important.

g. A specific model that can be used to estimate the flux over different climates in the absence of in situ data is generally unavailable.

\section{Acknowledgments}

The author acknowledges the contributions, financial support and assistance of Professor Oluwagbemiga Olawale Jegede, head of the Atmospheric Research Group of the Department of Physics and Engineering Physics, Obafemi Awolowo University, Ile-Ife, Nigeria, and other members of this group, for facilitating the setting up of the automated meteorological station. The support of the International Programme in the Physical Sciences (IPPS), Uppsala University, Sweden, and the University of Bayreuth, Germany through equipment donations, are also appreciated. The suggestions and contributions of the anonymous reviewers that have improved the quality of this manuscript are highly acknowledged.

\section{References}

Alaa MA, Ali MA, Yaseen KA. 2017. Parameterization of the downward long wave radiation under clearsky condition in Baghdad, Iraq. Asian Journal of Applied Sciences 10: 10-17. https://doi.org/10.3923/ ajaps.2017.10.17

Alados I, Foyo-Moreno I, Alados-Arboledas L. 2011. Estimation of downwelling longwave irradiance under all-sky conditions. International Journal of Climatology 32, 781-793. https://doi.org/10.1002/joc.2307

Ångström A. 1929. On the atmospheric transmission of sun radiation and on dust in the air. Geografiska Annaler 2: 156-166. https://doi.org/10.2307/519399

Arya SP. 2001. Introduction to micrometeorology. Academic Press, San Diego.

Ayoola MA, Sunmonu LA, Bashiru MI, Jegede OO. 2014. Measurements of net all-wave radiation at a Tropical Location, Ile-Ife, Nigeria. Atmósfera 27: 305-315. https://doi.org/10.1016/S0187-6236(14) 71118-X

Balogun AA. Jegede OO, Olaleye JO. 2003. Surface radiation budget over bare soil at Ile-Ife, Nigeria. Nigerian Journal of Solar Energy 14: 6-13. https://doi. org/10.5923.j.ijee.20150505.02
Bilbao J, de Miguel AH. 2007. Estimation of daylight downward longwave atmospheric irradiance under clear-sky and all-sky conditions. Journal of Applied Meteorology and Climatology 46: 878-889. https:// doi.org/10.1175/JAM2503.1

Brutsaert W. 1975. On a derivable formula for longwave radiation from clear skies. Water Resources Research 11: 742-744. https://doi.org/10.1029/ WR011i005p00742

Carmona F, Rivas R, Caselles C. 2014. Estimation of daytime downward longwave radiation under clear and cloudy skies conditions over a sub-humid region. Theoretical and Applied Climatology 115: 281-295. https://doi.org/10.1007/s00704-013-0891-3

Choi M, Jacobs JM, Kustas WP. 2008. Assessment of clear and cloudy sky parameterizations for daily downwelling longwave radiation over different land surfaces in Florida, USA. Geophysical Research Letters 35: L20402. https://doi.org/10.1029/2008GL035731

Crawford TM, Duchon CE. 1999. An improved parameterisation for estimating effective atmospheric emissivity for use in calculating daytime downwelling longwave radiation. Journal of Applied Meteorology 38: 474-480. https://doi.org/10.1175/1520-0450(1999)038<0474: AIPFEE $>2.0 . \mathrm{CO} ; 2$

CulfAD, Gash JHC. 1993. Longwave radiation from clear skies in Niger: A comparison of observations with simple formulas. Journal of Applied Meteorology 32: 539-547. https://doi.org/10.1175/1520-0450(1993)032<0539:LRFCSI $>2.0 . \mathrm{CO} ; 2$

Dale VH. 1997. The relationship between land use change and climate change. Ecological Applications 7: 753769. https://doi.org/10.1890/1051-0761(1997)007[07 53:TRBLUC]2.0.CO;2

Deacon EL. 1970. The derivation of Swinbank's longwave radiation formula. Quarterly Journal of the Royal Meteorological Society 96: 313-319. https:// doi.org/10.1002/qj.49709640814

Dilley AC, O’Brien DM. 1998. Estimating downward clear sky longwave irradiance at the surface from screen temperature and precipitable water. Quarterly Journal of the Royal Meteorological Society 124: 1391-1401. vhttps://doi.org/10.1002/qj.49712454903

Duarte HF, Dias NL, Maggiotto SR. 2006. Assessing daytime downward longwave radiation estimates for clear and cloudy skies in Southern Brazil. Agricultural and Forest Meteorology 139: 171-181. https://doi. org/10.1016/j.agrformet.2006.06.008 
Falaiye, OA, Babatunde EB, Willoughby AA. 2014. Atmospheric aerosol loading at Ilorin, a tropical station. The African Review of Physics 9: 527-535.

Garratt JR. 1992. The atmospheric boundary layer. Cambridge University Press, 336 pp.

Griffiths JF. 1974. Climates of Africa. In: Future climates of the world: a modelling perspective (Landsberg HE, Ed.). Elsevier, 167-187 (World Survey of Climatology 10).

Gröbner J, Wacker S, Vuilleumier L, Kämpfer N. 2009. Effective atmospheric boundary layer temperature from longwave radiation measurements. Journal of Geophysical Research 114: D19116. https://doi. org/10.1029/2009JD012274

Guest PS. 1998. Surface longwave radiation conditions in the Eastern Weddell Sea during winter. Journal of Geophysical Research 103: 761-772. https://doi. org/10.1029/98JC02146

Guo Y, Cheng J, Liang S. 2018. Comprehensive assessment of parameterization methods for estimating clearsky surface downward longwave radiation. Theoretical and Applied Climatology 135, 1045-1058. https://doi. org/10.1007/s00704-018-2423-7

Hastenrath S. 1991. Climate dynamics of the tropics. Kluwer Academic Publishers, Dordrecht.

Hayward DF, Oguntoyinbo JS. 1987. The climatology of West Africa. Rowan and Littlefield, New York.

Howard R, Stull R. 2013. Modeling the downwelling longwave radiation over a groomed ski run under clear skies. Journal of Applied Meteorology and Climatology 52: 1540-1553. https://doi.org/10.1175/ JAMC-D-12-0245.1

Idso SB, Jackson RD. 1969. Thermal radiation from the atmosphere. Journal of Geophysical Research 74: 5397-5403. https://doi.org/10.1029/JC074i023p05397

Idso SB. 1981. A set of equations for full spectrum and 8- to $14-\mu \mathrm{m}$ and 10.5 - to $12.5-\mu \mathrm{m}$ thermal radiation from cloudless skies. Water Resources Research 17: 295-304. https://doi.org/10.1029/WR017i002p00295

Iziomon MG, Mayer H, Matzarakis A. 2003. Downward atmospheric longwave irradiance under clear and cloudy skies: measurement and parameterisation. Journal of Atmospheric and Solar Terrestrial Physics 65: 1107-1116. https://doi.org/10.1016/j.jastp.2003.07.007 Jegede OO, Ogolo EO, Aregbesola TO. 2006. Estimating net radiation using routine meteorological data at a tropical location in Nigeria. International Journal of Sustainable energy 25: 107-115. https://doi. org/10.1080/14786450600593261
Kessler A, Jaeger L. 1999. Long term changes in net radiation and its components above a pine forest and a grass surface in Germany. International Journal of Climatology 19: 211-226. https://doi.org/10.1002/(SICI)10970088(199902)19:2<211::AID-JOC351>3.0.CO;2-1

Key JR, Schweiger AJ. 1998. Tools for atmospheric radiative transfer: STREAMER and FLUXNET. Computers and Geosciences 24: 443-451. https://doi.org/10.1016/ S0098-3004(97)00130-1

Kjaersgaard JH, Plauborg FL, Hansen S. 2007. Comparison of models for calculating daytime long-wave irradiance using long term dataset. Agricultural and Forest Meteorology 143: 49-63. https://doi.org/10.1016/j. agrformet.2006.11.007

Kneizys FX, Shettle EP, Abreu LW, Chetwynd JH, Anderson GP, Gallery WO, Selby JEA, Clough SA. 1988. Users guide to LOWTRAN7. Environmental Research Papers 1010AFGL-TR- 88-0177. Air Force Geophysics Laboratory, Hanscom AFB, Bedford.

Kruk NS, Vendrame I.F, Rocha HR, Chou SC, Cabral O. 2010. Downward longwave radiation estimates for clear and all-sky conditions in the Sertãozinho region of São Paulo, Brazil. Theoretical and Applied Climatology 99: 115-123. https://doi.org/10.1007/s00704-009-0128-7

Lhomme JP, Vacher JJ, Rocheteau A. 2007. Estimating downward long-wave radiation on the Andean Altiplano. Agricultural and Forest Meteorology 145: 139-148. https://doi.org/10.1016/j.agrformet.2007.04.007

Niemela S, Raisanen P, Savijarvi H. 2001. Comparison of surface radiative flux parameterisations part I: longwave radiation. Atmospheric Research 58: 1-18. https://doi.org/10.1016/S0169-8095(01)00084-9

Oke TR. 2002. Boundary layer climates. 2nd ed. Routledge, London.

Okogbue EC. 1997. A study of solar and infrared radiation fluxes over a tropical station, Ile-Ife. M.Sc. Thesis. Obafemi Awolowo University, Ile-Ife, Nigeria.

Oladosu OR, Jegede OO, Sunmonu LA, Adeddeji AT. 2007. Bowen ratio estimation of surface energy fluxes in a limited tropical agricultural site, Ile-Ife, Nigeria. Journal of Radio and Space Physics 36: 213-218.

Paltridge GW, Platt CMR. 1976. Radiative processes in meteorology and climatology. Elsevier Scientific, $336 \mathrm{pp}$.

Prata AJ. 1996. A new long-wave formula for estimating downward clear-sky radiation at the surface. Quarterly Journal of the Royal Meteorological Society 122: 1127-1151. https://doi.org/10.1002/qj.49712253306 
Ricchiazzi P, Yang S, Gautier C, Sowle D. 1998. SBDART: A research and teaching software tool for plane-parallel radiative transfer in the Earth's atmosphere. Bulletin of the American Meteorological Society 79: 2101-2114. https://doi.org/10.1175/1520-0477(1998)079<2101: SARATS $>2.0 . \mathrm{CO} ; 2$

Santos CA, da Silva BB, Rao TVR, Satyamurty P, Manzi AO. 2011. Downward longwave radiation estimates for clear-sky conditions over Northeast Brazil. Revista Brasileira de Meteorologia 26: 443-450. https://doi. org/10.1590/S0102-77862011000300010

Snell HE, Anderson GP, Wang J, Moncet JL, Chetwynd JH, English SJ. 1995. Validation of FASE (FASCODE for the environment) and MODTRAN3: Updates and comparisons with clear sky measurements. In: Passive Infrared remote sensing of clouds and the atmosphere III. Proceedings 2578, Satellite Remote Sensing II, Paris, France, 194-204. https://doi.org/10.1117/12.228940

Soneye OO. 2018. Investigation of the effect of atmospheric aerosol loading on the surface radiation balance at Ile-Ife, Southwest Nigeria. Ph.D. thesis. Obafemi Awolowo University, Ile-Ife, Nigeria.
Soneye OO, Ayoola MA, Ajao IA, Jegede OO. 2019. Diurnal and seasonal variations of the incoming solar radiation flux at a tropical station, Ile-Ife, Nigeria. Heliyon 5: e01673. https://doi.org/10.1016/j.heliyon.2019.e01673

Sozzi R, Salcido A, Flores RS, Georgiadis T. 1999. Daytime net radiation parameterisation for Mexico City Suburban Areas. Atmospheric Research 50: 53-68. https://doi.org/10.1016/S0169-8095(98)00088-X

Staley DO, Jurica GM. 1972. Effective atmospheric emissivity under clear skies. Journal of Applied Meteorology 11: 349-356. https://doi.org/10.1175/1520-0450 (1972)011<0349:EAEUCS >2.0.CO;2

Swinbank WC. 1963. Long-wave radiation from clear skies. Quarterly Journal of the Royal Meteorological Society 89: 339-348. https://doi.org/10.1002/ qj. 49708938105 


\section{Supplementary materials}

$C_{A}=\frac{S_{\downarrow M}}{S_{\downarrow} c}$

where $S_{\downarrow M}$ is the measured incoming solar radiation at the surface and $S_{\downarrow} c$ is the calculated incoming solar radiation under cloudless sky condition expressed by Stull (1989) as:

$$
\left\{\begin{array}{ll}
S_{o} \tau_{K} \sin \Psi, & \Psi>0 \\
0, & \Psi<0
\end{array}\right\}
$$

where $S_{o}$ is the solar constant $=1367 \mathrm{Wm}^{-2} ; \Psi$ is the solar elevation angle between $0^{\circ}$ and $90^{\circ}$, which is $\geq 0$ and $\leq 0$ for daytime and night-time conditions, respectively, and $\tau_{K}$ is the atmospheric transmissivity expressed for clear sky conditions as $\tau_{K}=0.6+0.2$ $\sin \Psi$ by Jegede et al. (2006).

Correlation coefficient,

$\mathrm{R}=\frac{\sum_{i=1}^{n}\left(E t_{i}-\overline{E t}\right)\left(M d_{i}-\bar{M} d\right)}{\sqrt{\sum_{i=1}^{n}\left(E t_{i}-\overline{E t}\right)^{2} \sum_{i=1}^{n}\left(M d_{i}-\overline{M d}\right)^{2}}}$

Coefficient of determination,

$R^{2}=\left(\frac{\sum_{i=1}^{n}\left(E t_{i}-\overline{E t}\right)\left(M d_{i}-\overline{M d}\right)}{\sqrt{\sum_{i=1}^{n}\left(E t_{i}-\overline{E t}\right)^{2} \sum_{i=1}^{n}\left(M d_{i}-\overline{M d}\right)^{2}}}\right)^{2}$

Mean bias error,

$\mathrm{MBE}=\frac{1}{n} \sum_{i=1}^{n}\left(E t_{i}-M d_{i}\right)$

Mean absolute error,

$\mathrm{MAE}=\frac{1}{n} \sum_{i=1}^{n}\left|E t_{i}-M d_{i}\right|$

Root mean square error,

$\mathrm{RMSE}=\sqrt{\frac{1}{n} \sum_{i=1}^{n}\left(E t_{i}-M d_{i}\right)^{2}}$

Relative mean bias error,
$\mathrm{RMBE}=100 .\left[\frac{\frac{1}{n} \sum_{i=1}^{n}\left(E t_{i}-M d_{i}\right)}{\overline{M d}}\right]$

Relative root mean square error,

$\operatorname{RRMSE}=100 \cdot\left[\frac{\sqrt{\frac{1}{n} \sum_{i=1}^{n}\left(E t_{i}-M d_{i}\right)^{2}}}{\overline{M d}}\right\rfloor$

Relative mean absolute error,

RMAE $=100 .\left\lfloor\frac{\sqrt{\frac{1}{n} \sum_{i=1}^{n}\left|E t_{i}-M d_{i}\right|^{2}}}{\overline{M d}}\right\rceil$

Index of agreement,

$d=1-\left[\frac{\sum_{i=1}^{n}\left(E t_{i}-M d_{i}\right)^{2}}{\sum_{i=1}^{n}\left(\left|E t_{i}-\overline{M d}\right|+\left|\left(M d_{i}-\overline{M d}\right)\right|\right)^{2}}\right]$

where $M d$ is the measured downward longwave radiation, Et is the estimated downward longwave radiation, $\overline{M d}$ is the mean of the measured downward longwave radiation, $\overline{E t}$ is the mean of the estimated downward longwave radiation, and $n$ is the number of observations.

$L_{\downarrow C l}=\left[d\left(\frac{e_{0}}{T_{A}}\right)^{g}\right] \sigma T_{A}^{4}$

where $d$ and $g$ are local coefficients. The units of $e_{0}$ and $T_{A}$ are $\mathrm{hPa}$ and $\mathrm{K}$, respectively.

$L_{\downarrow C l}=\left[1.064\left(\frac{e_{0}}{T_{A}}\right)^{0.053}\right] \sigma T_{A}^{4}$

\section{References}

Jegede OO, Ogolo EO, Aregbesola TO. 2006. Estimating net radiation using routine meteorological data at a tropical location in Nigeria. International Journal of Sustainable energy 25: 107-115. https://doi. org/10.1080/14786450600593261

Stull RB. 1989. An introduction to boundary layer meteorology. Kluwer Academic Publisher. 